\title{
Cattle vaccination records question the impact of recent zero-deforestation agreements in the Amazon
}

\author{
Michael Klingler $^{1} \cdot$ Peter D. Richards ${ }^{2} \cdot$ Roman Ossner $^{1}$
}

Received: 5 October 2015 / Accepted: 10 October 2017 /Published online: 6 November 2017

(C) The Author(s) 2017. This article is an open access publication

\begin{abstract}
In the late 2000s, slaughterhouses across the Amazon entered into a series of agreements designed to reduce the environmental impact of the local cattle sector. In this research, we analyze the impact of these agreements using a novel dataset showing the location of cattle vaccinations in 2014. In total, we estimate that more than half of the cattle herd in Novo Progresso was vaccinated on ranchlands which were either located in protected areas, were deforested since the agreements were put into place, were subject to an official embargo due to a violation of environmental or labor laws, or were not registered in the state of Pará's Rural Environmental Registry. The results suggest that hundreds of thousands of cattle continue to graze on areas in Southwest Pará which were meant to be excluded, per the terms of the recent cattle agreements, from the supply chain in a key Amazon cattle frontier. Our results highlight the importance of developing new systems for monitoring cattle supply chains in remote areas of the Amazon.
\end{abstract}

Keywords Deforestation - Cattle ranching $\cdot$ Cattle agreements $\cdot$ Supply chain governance $\cdot$ Amazon

Michael Klingler

michael.klingler@uibk.ac.at

1 Institute of Geography, Universität Innsbruck, Innrain 52f, 6020 Innsbruck, Austria

2 Bureau for Food Security, US Agency for International Development, Washington DC, USA

\section{Introduction}

Supply chain agreements have been hailed as innovative, market-driven solutions for reducing forest loss. They have also been viewed as critical for ensuring sustainable production and accountability in the supply chain. There is perhaps nowhere where supply chain initiatives have been thought to be more effective than the Brazilian Amazon, where zerodeforestation commitments between private, public, and multilateral actors have reshaped both the soybean and beef sectors (Gibbs et al. 2015a, b; Meyer and Miller 2015; Rudorff et al. 2011). This includes the 2006 soybean moratorium and the more recent 2009 cattle agreements. The latter agreements, the focus of this article, include high-profile commitments by major meatpacking companies operating across the Amazon basin to stop purchasing cattle from properties linked to illegal deforestation or other social or environmental standards. These agreements have been widely applauded, although the extent of their impact on reducing forest loss in the Amazon remains unclear (Araújo et al. 2015; Gibbs et al. 2015a; Pacheco et al. 2017).

This article focuses on the impact of the two principal cattle agreements on cattle production in a key and critical deforestation frontier in the Amazon state of Pará. Notably, it addresses the publically supported and legally binding Terms of Adjustment of Conduct (TAC) and the private-led G4 zero-deforestation cattle agreement, two supply chain interventions designed to reshape the nature of the cattle sector and reduce cattle-driven forest loss. Using a unique dataset showing the location of cattle in southwestern Pará state in 2014 , this research shows that $27 \%$ of the local cattle herd, or nearly 318,000 animals, were grazing on properties which were illegally or recently deforested, or which were under official property embargoes. All of these areas, per the TAC cattle agreement, were meant to be excluded from the cattle 
sector. We further estimate that an additional 166,000 cattle were grazing on areas which were not registered in the Rural Environmental Registry (Cadastro Ambiental Rural (CAR)). Thus, our findings imply that approximately $57 \%$ of the total cattle herd in the municipality of Novo Progresso was grazing on pastures, which should have been off limits to signatories of the major cattle agreements in the Amazon. This research thus sheds light on the pervasiveness of cattle laundering and leakage in the Amazon and the difficulty of adequately monitoring and tracking beef cattle, particularly in remote regions.

We develop and present our findings in four parts. First, we highlight the recent policies and trends which gave rise to, and then helped to control, deforestation in the Brazilian Amazon. Here, we focus on three key policy changes: (a) the so-called cattle agreements, which were designed to decouple cattle production from deforestation; (b) the rural environmental registry, mandated for large properties after 2008; and (c) the mandatory febre aftosa (also commonly known as foot-andmouth disease (FMD)) control program. Second, we introduce our study area, the remote cattle regions of southwestern Pará state, and describe our datasets on land use and land cover change, property boundaries, and cattle locations. Third, we present our results showing that cattle were clearly grazing on areas which, per the cattle agreements, were meant to be off limits to the cattle sector. Fourth, and finally, we close with a section on the difficulties associated with accurately and comprehensively monitoring the movement of certified cattle. We then suggest that future supply chain agreements must seek new tools and publically accessible datasets for managing the environmental impact of the Amazon cattle sector. Specifically, we argue that interventions into the cattle sector must monitor cattle rather than ranches.

\section{Deforestation and the cattle agreements}

In the early 2000s, deforestation rates were rising across the Brazilian Amazon and nowhere more so in the states of Mato Grosso and Pará (INPE 2017). The rise in forest loss was widely tied to a series of political, economic, and infrastructure shifts during the late 1990s and early 2000s. This includes (a) policy reforms for export crops (DeFries et al. 2013; Helfand and Castro de Rezende 2004), (b) improvements in transportation and accessibility (Walker et al. 2009), (c) the control of FMD (Bowman 2016; Kaimowitz et al. 2004), and (d) the favorable evolution of local soybean and beef markets (Macedo et al. 2012; Nepstad et al. 2006; Richards et al. 2012). Much of the deforestation that then followed was linked, directly or indirectly to cattle and soybean production.

The rising rates of forest loss in the Amazon, and the linkages between deforestation and the cattle sector especially, did not go unnoticed by policy makers or environmental interests. Their concerns led, in turn, to the deployment of a series of innovative policies for controlling and combating illegal deforestation while building a path to achieving zerodeforestation goals in the Amazon (Moutinho et al. 2016; Nepstad et al. 2014). In 2004, the Brazilian government launched its first Plan for Prevention and Control of Deforestation in the Legal Amazon (PPCDAm I). Under PPCDAm I, more than $900,000 \mathrm{~km}^{2}$ of protected areas and indigenous territories were established (CEPAL et al. 2011; WDPA 2016). Few years later, under PPCDAm II, additional policies were put into place to limit access to public financing and markets in deforestation hotspots and new systems were created to enforce environmental crime laws and identify outof-compliance landowners (Arima et al. 2014; Assunção and Rocha 2014; Azevedo et al. 2015; Schmitt 2015). Thereafter, property owners who did not comply with legal forest reserve requirements faced potential credit restrictions, police raids, property and machinery seizure, and even arrest (Börner et al. 2015; Cisneros et al. 2015; Sills et al. 2015). In the mid-2000s, the states of Mato Grosso and Pará also began requiring property owners to submit their property boundaries to state-run Rural Environmental Registries, known in Brazil as CAR (Pires 2013). The CAR not only helped state governments identify property boundaries and land claims (including claims with or without formal property rights) but also provided new information on which properties were in or out of compliance with the Forest Code (Azevedo et al. 2015; Chomitz and Wertz-Kanounnikoff 2005; Richards and VanWey 2015; Soares-Filho et al. 2014; Stickler et al. 2013).

The public policy efforts to reduce forest loss were complemented by a series of market-based or demand-led policy instruments. These innovative policies sought to channel consumer and corporate preferences for green products into farm or field-level change. The first such major effort in the Amazon, the soybean moratorium, brought together a consortium of soybean famers' organizations, agricultural commodity traders, and environmental organizations. Under the soybean moratorium agreement, Brazil's major soybean traders would cease purchasing soybeans from farms which deforested land after July 2006 (Gibbs et al. 2015b; Rausch and Gibbs 2016; Rudorff et al. 2011). The soybean moratorium has since been widely credited with reducing farm-level incentives to open new farmland.

In July 2009, the cattle sector, stimulated by a high-profile Greenpeace campaign on illegal beef operations in the Amazon (Greenpeace Brasil 2009) and in response to lawsuits initiated by the Federal Public Prosecutor's Office (Ministério Público Federal (MPF)) and IBAMA, followed the lead of the soybean supply chain. After suing ranchers and slaughterhouses involved in the illegal cattle supply chain, MPFPará's strategy to encourage Brazilian retailers to boycott began to bear fruit (Barreto and Silva 2011). That year, slaughterhouses across the Legal Amazon began signing legally binding cattle agreements, also known as the TAC da Carne, with the MPF (e.g., MPF 2009a, b; MPF 2010). Two thirds of 
the federal inspected major slaughterhouses (Serviço de Inspeção Federal (SIF)) eventually signed the TAC agreements (Gibbs et al. 2015a), meaning that they thereafter committed to refuse cattle purchases from direct suppliers (1) whose cattle production was linked to properties which had deforested illegally (as defined by Brazil's Forest Code), (2) which were under some form of environmental embargo, or (3) which do not meet several key environmental or social criteria (e.g., CAR registry or slave labor) (Azevedo 2014; Pacheco et al. 2017). In October 2009, the TAC agreement was followed by a private-led G4 zero-deforestation cattle agreement with Brazil's largest meatpacking companies, JBS/Friboi, Bertin, Minerva, and Marfrig. The G4 went beyond the TAC agreements by excluding any properties which had deforested, regardless of legality (Greenpeace International 2009). Both versions of the cattle agreements relied on the CAR registry to monitor the legal documentation of the properties. While the impact of the cattle agreements has been questioned, largely owing to concerns over cattle laundering, the agreement did succeed in driving an increase in CAR property registrations (Gibbs et al. 2015a).

The TAC and G4 agreements shared many similarities to the soybean moratorium, which sought to leverage satellite information on crop production and information on recent deforestation to identify out-of-compliance soybean areas. Notably, both the cattle agreements and the soybean moratorium focused on leveraging commodity purchasers' influences over farm or ranch-level producers. The cattle agreements, however, would have to overcome several key obstacles. First, cattle, unlike soybeans, are mobile and often breed or fatten on multiple ranches over their lifetime. Given that cattle agreements focus only on the properties associated with an animal at that animal's specific point of sale, animals could be raised on areas which were meant to be excluded by the cattle agreements. If these animals are later sold to a rancher who is then in-compliance, they could then be sold legally to a slaughterhouse which had signed the TAC or G4 agreements. Therefore, it is a serious weakness that both cattle agreements do not monitor effectively calving ranches or intermediaries supplying indirectly to fattening ranches or slaughterhouses. Second, cattle graze in some of the most remote regions of the Amazon. These remote areas are oftentimes the very areas which agreements such as the TAC and G4 agreements are most needed to protect. Yet they are also often the most costly and time consuming to monitor. The land tenure situation is widely unresolved in these regions, making it even more difficult to tie animals to specific ranchers or ranch owners (Benatti and da Cunha Fischer 2017; Brito and Cardoso 2015; Pacheco and Benatti 2015). Third, monitoring cattle raised in difficult-to-access areas is both costly and complicated. Cattle, especially when compared to soybeans, are not reliably tracked through satellite imagery. Accurate traceability within the supply chain would require new tracking technologies such as GPS-based ear tags and a fully transparent cattle transportation system. Currently, this process is suggested but not authorized by the animal transit guide, GTA (Guia de Transporte Animal), which tracks movement of cattle between farms and slaughterhouses (ADEPARÁ 2017; Barreto et al. 2017). Fourth and finally, in comparison to the soybean sector, the cattle supply chain offers a broader array of potential purchasers for ranchers. While the soybean sector is dominated by a handful of major grain traders, the cattle sector is significantly more complex, with hundreds of potential slaughterhouse outlets. While many of the largest slaughterhouses in the Amazon did sign the TAC or G4 agreements, many smaller and medium-sized slaughterhouses did not. According to Barreto et al. (2017), as of 2016, 157 (128 of which were active) federal and state-inspected (Sistema de Inspeção Estadual (SIE)) slaughterhouses were responsible for $93 \%$ of the total slaughter capacity in the Amazon. TAC signatories were then responsible for $70 \%$ of this capacity in the region. The presence of non-TAC signatories (representing an estimated $30 \%$ of total regional capacity) could provide an outlet for cattle raised on areas which should have been off limits, per the cattle agreements. Such outlets could enable ranchers to avoid the standards set by the TAC or G4 cattle agreements (Garcia-Drigo et al. 2016; Walker et al. 2013).

Given these difficulties, the effectiveness of the cattle agreements in reducing forest loss has already been brought into question (Gibbs et al. 2015a). We build on these past efforts, however, by providing evidence of the extent to which the cattle sector continues to operate on areas which, per the cattle agreements, were meant to be off limits. As we show in this article, hundreds of thousands of cattle continued to graze on areas which should have been off limits per the cattle agreements. While we refrain from explaining how ranchers avoid compliance with the TAC or G4 cattle agreements, our findings do suggest that the TAC agreements have had limited impact in reducing the illegal cattle herd in Southwest Pará, a key ranching area in the Brazilian Amazon.

\section{Material and methods}

\section{Study area}

Southwest Pará is one of the most dynamic and fastest growing cattle regions in the Brazilian Amazon. The region includes the municipality of Novo Progresso and areas pertaining to Altamira, Itaituba, and Jacareacanga, which were located along the federal highway BR-163 corridor. Novo Progresso serves as the region's economic and political hub, particularly for the cattle sector (Fig. 1). The area encompasses, in total, more than $100,000 \mathrm{~km}^{2}$; most of the area remains forested $\left(86,657 \mathrm{~km}^{2}\right)$, although more than $9000 \mathrm{~km}^{2}$ of land has been opened for pasture (Terra Class 

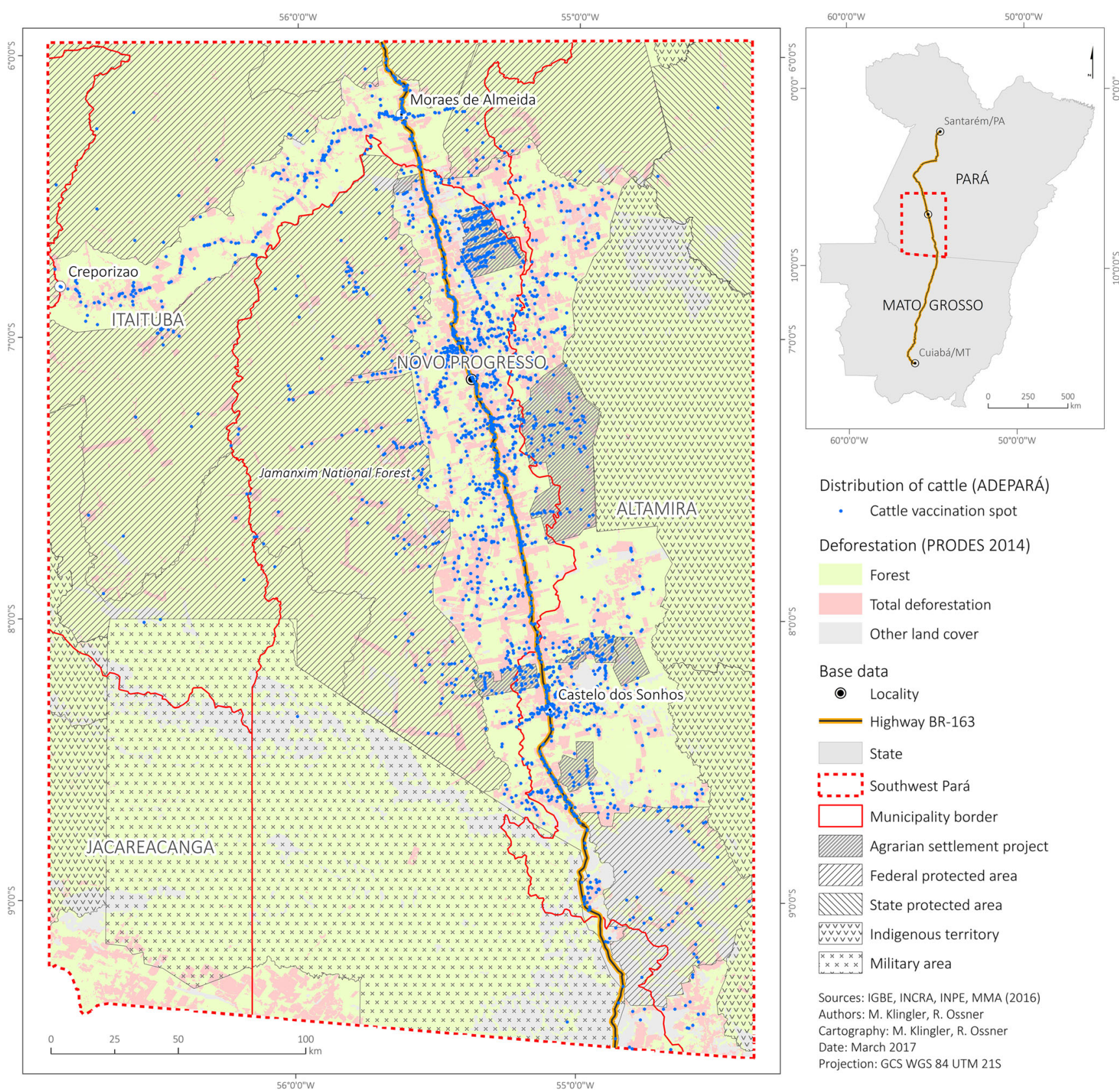

Distribution of cattle (ADEPARÁ)

- Cattle vaccination spot

Deforestation (PRODES 2014)

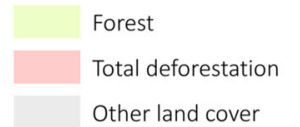

Base data

- Locality

— Highway BR-163

State

:-...: Southwest Pará

$\square$ Municipality border

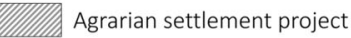

VIIIA Federal protected area

MII state protected area

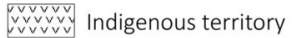

$\left[\begin{array}{cc}x \times x \times y \\ x \times x \times x\end{array}\right.$ Military area

Sources: IGBE, INCRA, INPE, MMA (2016)

Authors: M. Klingler, R. Ossner

Cartography: M. Klingler, R. Ossner

Date: March 2017

Projection: GCS WGS 84 UTM 215

Fig. 1 Distribution of foot-and-mouth disease administration sites in Southwest Pará

2014; INPE and Embrapa 2016). Much of the region (74.3\%) is under some form of complete or partial protection, whether as federal or state conservation units (UCF, UCE), indigenous territories (TI), or as a military base (AM). A small fraction $(2.5 \%)$ of the region has been allocated for governmentsponsored agrarian settlement projects (ASPs).

Southwestern Pará is heavily influenced by a north-south highway transect known as the Cuiabá-Santarém Highway, or BR-163. Improvements to the highway in the 2000s, combined with the rapid growth in the soybean sector and increasing values for pasture farther south in Mato Grosso, combined to attract a wave of investors to the region (Coy et al. 2017;
Fearnside 2007; Richards et al. 2014; Torres et al. 2005). Cattle farmers, loggers, and land speculators have since arrived and created a lucrative market-driven cattle sector (Campbell 2014; Castro et al. 2010). Expanding the herd, however, required clearing and creating new pastures. Over the course of the 2000s, deforestation surged. In Novo Progresso, between 2000 and 2014, $280 \mathrm{~km}^{2}$ of forest was lost each year, largely for grazing lands (INPE 2017). Concurrently, Novo Progresso's cattle herd increased by $500 \%$, or from 100,000 to more than 600,000 head of cattle (ADEPARÁ 2014). Today, across the larger Southwest Pará region, the total herd exceeds 1.1 million animals (Table 1). 
Table 1 Mean statistics of cattle ranching in Southwest Pará (2014)

\begin{tabular}{|c|c|c|c|c|c|c|}
\hline \multirow[t]{2}{*}{ Variable } & \multicolumn{3}{|c|}{ Novo Progresso } & \multicolumn{3}{|c|}{ Southwest Pará } \\
\hline & Count & $\mathrm{km}^{2}$ & $\%$ & Count & $\mathrm{km}^{2}$ & $\%$ \\
\hline Total deforested area (PRODES 2014) & & 5517.9 & & & $12,163.5$ & \\
\hline Total pasture area (Terra Class 2014) & & 4133.8 & & & 9059.3 & \\
\hline Clean pasture & & 3524.4 & 85.2 & & 7586.4 & 83.8 \\
\hline Woody pasture & & 444.8 & 10.8 & & 980.7 & 10.8 \\
\hline Pasture with exposed soil & & 1.1 & 0 & & 1.5 & 0 \\
\hline Regeneration with pasture & & 167.5 & 4.1 & & 490.7 & 5.4 \\
\hline Heads of cattle (ADEPARÁ 2014) & 612,704 & & & $1,178,043$ & & \\
\hline Cattle farm holdings & 1589 & 9241.7 & & 2835 & $17,597.4$ & \\
\hline
\end{tabular}

Sources: ADEPARÁ (2014), INPE (2016)
Novo Progresso has been heavily affected by recent policy interventions to slow forest loss in the Amazon. Seven protected areas, amounting to nearly $40,000 \mathrm{~km}^{2}$ in total, were created or expanded in the municipal region during the late 2000s (Martins et al. 2012; WDPA 2016). Another $13,000 \mathrm{~km}^{2}$ was set aside in expanded indigenous reserves (Table 3). In 2008, the municipality was also added to the so-called (Black-)List of Priority Municipalities (Federal Decree 6.321/07). As a Blacklist Municipality, Novo Progresso was subject to additional law enforcement and limited access to finance (Resolution Nr. 3.545). Between 2008 and 2014, for example, the environmental police carried out 1300 field operations (MMA and IBAMA 2014). Many of the targeted properties would later be put under a property embargo (Fig. 2). Their landowners were also liable to fines or subject to additional restrictions on financing. Such command and control efforts affected not only landowners' public reputations (Cisneros et al. 2015) but also their businesses operations (Assunção and Rocha 2014; Sousa 2016). These policies and enforcement efforts, however, were thought to be highly effective in reducing forest loss. Between 2004 and 2014, across Southwest Pará, deforestation fell by $70 \%$. In Novo Progresso specifically, deforestation fell by $85 \%$ (INPE 2017).

For our analysis, we focused on Southwest Pará for several reasons. Notably, the region is a major cattle producer. It also remains in transition, with vast forest areas for potential clearing. Political efforts to stop illegal deforestation and land speculation here have also been met with heavy resistance. In 2011, for example, protesters invaded the local IBAMA office after confiscating 900 head of cattle as part of Operação Disparada. More recently, in 2014, a gang of local squatters was imprisoned in what is considered the largest illegal deforestation and land speculation conspiracy in Brazil in recent decades (Operação Castanheira, MPF 2014). Given local resistance to previous public efforts to reduce illegal forest loss and pasture expansion within protected areas and the importance of cattle ranching to the local economy, any cattle supply chain intervention is likely to be challenged and, if possible, evaded. Conversely, if non-compliant or illegal ranchers were able to subvert the cattle agreements, we hypothesized that they would be most likely to do so here.

\section{Datasets on land use and land cover change, property boundaries, and cattle locations}

To better understand the impact of the cattle agreements in Southwest Para, we compiled a series of spatial datasets concerning (a) deforestation, (b) land use, (c) cattle locations (as shown through vaccination records), (d) areas subject to environmental and social enforcement (an embargo or field operation), and (e) property boundaries. This data consisted of a series of administrative boundaries, property borders, point data, and land use classifications (see Table 2 for full descriptions and data sources).

For our annual analysis of deforestation during the period 2000-2014, we used deforestation data provided by the Amazon Deforestation Monitoring Project PRODES (Projeto de Monitoramento do Desflorestamento na Amazônia Legal) from Brazil's National Institute for Space Research (INPE 2017). Annual deforestation refers to forest loss between July 31 of 1 year and August 1 of the year before. For land use, we use data drawn from Terra Class, for the years 2004, 2008, 2010, 2012, and 2014 (INPE and Embrapa 2016). The Terra Class maps identify four types of pasture: clean pasture, woody pasture, pasture with exposed soil, and regeneration with pasture (we classify all of these land use types as pasture).

To understand the distribution of cattle, we drew from cattle locations as monitored by the Brazil-wide vaccination campaign National Program of Eradication and Prevention of Foot and Mouth Disease (PNEFA, MAPA 2007). As part of the PNEFA annual report, the State of Pará's Cattle Protection Agency (ADEPARÁ) is responsible for executing, controlling, and assessing the vaccination of the state's entire cattle herd (more than 20 million animals) against the aftos $a$ virus (Portaria Nr. 0409/2013; ADEPARÁ 2013). While in practice 

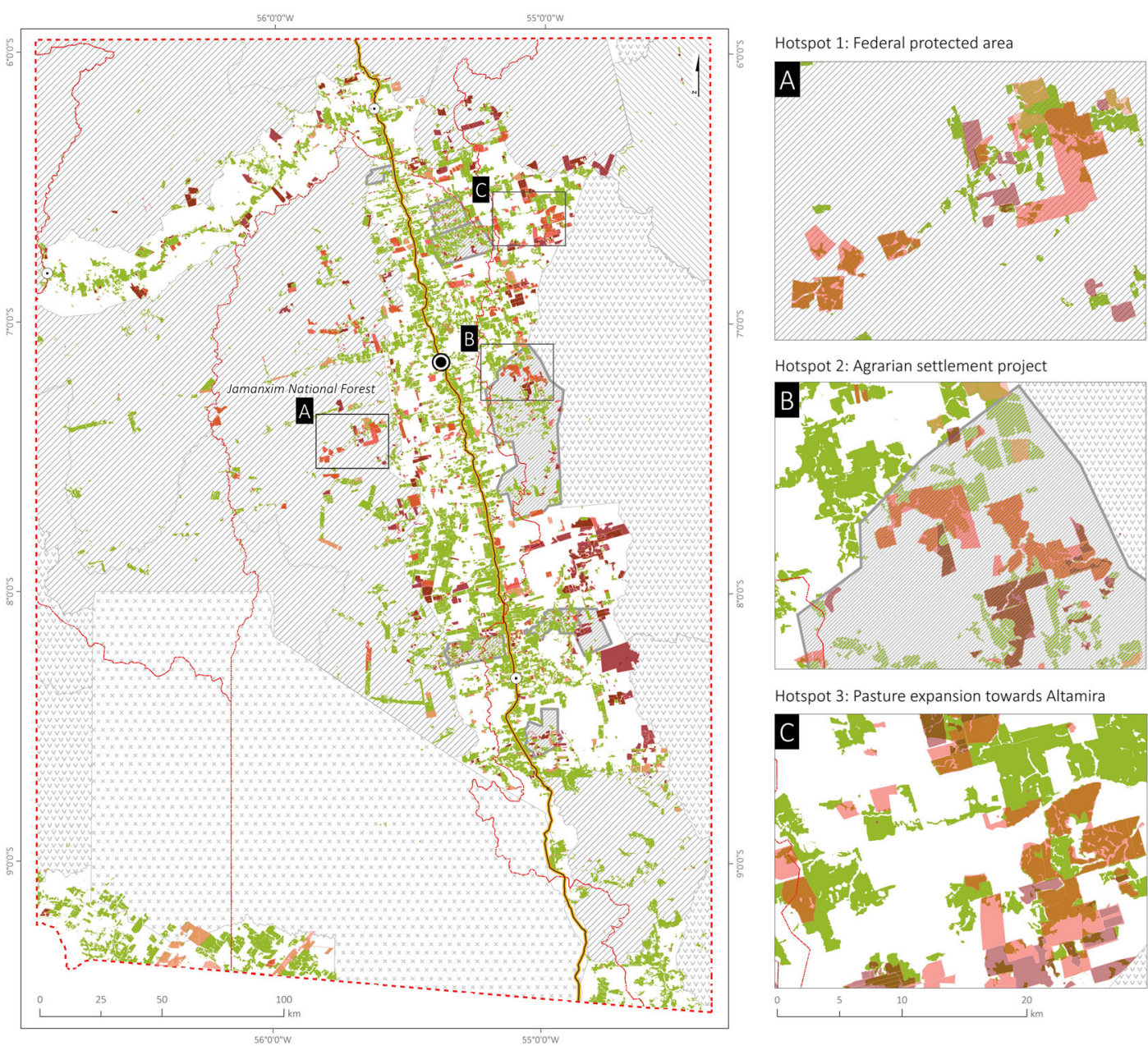

Enviromental embargoed area
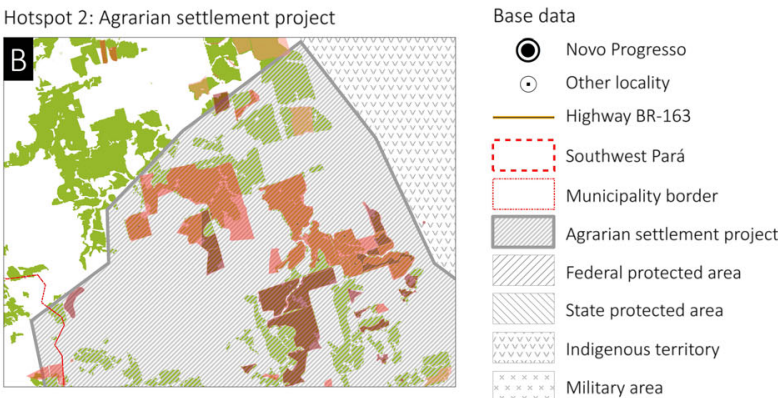

Hotspot 3: Pasture expansion towards Altamira

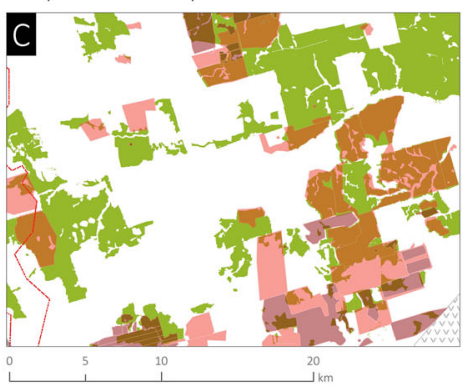

Sources: IBAMA, INCRA, INPE, MMA (2016) Authors: M. Klingler, R. Ossner Cartography: M. Klingler, R. Ossner Date: March 2017 Projection: GCS WGS 84 UTM 215

Fig. 2 Embargoed properties and pasture areas in Southwest Pará

ADEPARÁ is not directly administering FMD vaccinations on most ranches, the veterinarian monitoring service does collect binding information from local ranchers on vaccine invoices, on the number of vaccinated animals on his or her ranch, and on the locations at which the vaccinations were administered. After the vaccination, the self(rancher)-reported

Table 2 Data sources

\section{Data}

Military area [AM]

Protected areas [UCF, UCE]

Indigenous territories $[\mathrm{TI}]$

Agrarian settlement projects [ASP]

Annual deforestation rates in Mato Grosso and Pará (PRODES 2000-2014)

Land use/cover change data [Terra Class 2004, 2008, 2010, 2012, 2014]

Farm data [location of cattle vaccination, heads of cattle and voluntary information resp. size of total property incl. pasture and forest reserve] (2014)

Rural environmental registries [CAR] (2008-2014)

Land tenure regularization registries [TL] (2011-2014)

Environmental embargoed areas [EE] (2000-2014)

\section{Source(s)}

Brazilian Ministry of Environment (MMA)

MMA

MMA

Brazilian Federal Agrarian Agency (INCRA)

Brazilian National Institute of Space Research (INPE)

INPE

Agricultural and Livestock Defense Agency of the State of Pará (ADEPARÁ) (downloaded on May 2014)

State Secretary of Environment Pará (SEMAS-PA) [downloaded on May 2014]

Ministry for Agrarian Development (MDA) (downloaded on May 2014)

Brazilian Institute of Environment and Renewable Natural Resources (IBAMA) (downloaded on September 2014) 
results are checked against ADEPARÁ's cattle production and transfer registry. Ranchers who are out of compliance face further procedures (sanctions, fines, warnings, assisted or monitored vaccination among others) and will lose the GTA permission for intrastate and interstate animal transit (ADEPARÁ 2013; MAPA 2005). For agrarian settlement projects and indigenous areas, ADEPARÁ assistants do administer vaccinations.

Given the wide-scale recognition of the critical importance of maintaining an FMD-free cattle herd, and that ADEPARÁ's vaccination data carries no direct linkage to environmental monitoring or taxation, ranchers have a strong incentive to comply with the vaccinations and little incentive to avoid them. Consequently, the program is considered highly successful and comprehensive. Notably, the latest FMD report suggests that $99 \%$ of Pará's cattle herd was vaccinated as part of the program (MAPA 2016a, b). The vaccination data is often viewed as the most accurate indicator of the number and location of the state's cattle herd in a given year. In 2014, the year for which we obtained the FMD vaccination data, ADEPARÁ recorded more than 500,000 cattle vaccinations in Novo Progresso in 2014. Across the southwestern Pará region, a total of 1.1 million animals were vaccinated (Fig. 1 for map of administration points) (ADEPARÁ 2014).

In addition to land use data and information on cattle locations, we use data from Pará's CAR system to identify ranch boundaries in Novo Progresso. Per state regulations, landowners were required to have a valid CAR in order to sell cattle to retailers, traders, or slaughterhouses (Azevedo et al. 2014; Pires 2013), although CAR registrations did not start until the TAC cattle agreements were put into place in 2009 (Gibbs et al. 2015a). Our CAR dataset included two sets of data: the so-called temporary CAR data and the definitive CAR. The definitive CAR, in contrast to the temporary CAR, is a validated environmental registration authorized by the State Secretary of Environment Pará (SEMAS-PA). The combined temporary and definitive CAR datasets include 1515 registries: 1465 temporary and 50 definitive. Out of the entire $9900 \mathrm{~km}^{2}$ of land in Southwest Pará eligible for a CAR registration, approximately $5500 \mathrm{~km}^{2}$ was registered $\left(5200 \mathrm{~km}^{2}\right.$ was registered with a temporary CAR; only $250 \mathrm{~km}^{2}$ was registered with a definitive document).

We note that our CAR data was only available for Novo Progresso. We also note that our temporary CAR data was subject to a number of critical errors. Notably, many of the temporary CAR registries overlapped or were duplicated. In total, more than $9600 \mathrm{~km}^{2}$ of land was registered; however, nearly $40 \%$ of this was duplicative or overlapping with other claims. This occurred for several reasons: first, new landowners may have registered their properties after purchase, even if the former owner had already applied for the documentation; second, initial documents of registration stay in the database after revision; and third, some neighboring properties were drawn with overlapping boundaries. To ease comparison of the CAR data, we needed to create a single property layer. Following Richards and VanWey (2015), we cleaned the CAR data by removing, in the case of duplicate entries, temporary CAR registries where a definitive registry was available and old registries when a newer registry was included. We also deleted any overlapping slivers or edges. Our remaining CAR data consisted of 1176 temporary CAR and 50 definitive CAR registries.

The CAR datasets from both Pará and Mato Grosso have, in recent years, been used to better understand land use dynamics in the Amazon. Of note, Richards and VanWey (2015) leveraged CAR data in Mato Grosso to show that most of that state's remaining forest cover and biomass are located on large properties. Recent work by Gibbs et al. (2015a) also relied on the CAR dataset in Pará and showed that the CAR registration had become a critical factor for slaughterhouse sourcing. Effectively, they showed that, after the TAC agreements were put into place, the number of CAR-registered properties increased substantially.

By crossing the ADEPARÁ data with the CAR property data, as well as other property indicators (e.g., protected areas, embargoed properties, recently deforested ranches, or indigenous reserves), we can observe to what extent cattle are grazing on areas which should have been off limits to the cattle supply chain. If the TAC agreements were successfully eliminating cattle from areas which were not registered in Pará's CAR system, from restricted areas (protected areas and indigenous lands) or from areas which had deforested illegally after 2009 or which were under some form of environmental or social embargo (see public lists of environmental embargos issued by IBAMA and slave labor issued by the Ministry of Labor, MTE), then FMD vaccines should not have been administered in these areas (or on these properties). In Southwest Pará, one of the Amazon's most active frontiers (in terms of both deforestation and cattle production), hundreds of thousands of cattle were vaccinated in areas which, per the cattle agreements, should have been off limits (Table 3).

The analysis was complemented by the in situ fieldwork of the lead author, who lived and worked in Novo Progresso between 2010 and 2014. During this period, a series of structured questionnaires was administered to 132 farm holdings. The questionnaires gathered household information on the situation of cattle ranching, land tenure, environmental regularization, livelihood, migration histories, environmental perception, and sociocultural values. The survey data was georeferenced to facilitate "ground truth" information. In addition, a series of problem-centered interviews regarding supply chain interventions and zero-deforestation policies was realized in combination with participatory mapping methods, to identify social network relations and institutional barriers within the livestock sector. The interviews targeted rancher's unions and associations, as well as key figures in 
Table 3 Summary statistics of cattle ranching affected by environmental embargos in Southwest Pará (2014)

\begin{tabular}{|c|c|c|c|c|c|c|c|c|c|}
\hline \multirow{2}{*}{$\begin{array}{l}\text { Land status } \\
\text { Name (year created) }\end{array}$} & \multirow{2}{*}{$\begin{array}{l}\text { Area } \\
\mathrm{km}^{2}\end{array}$} & \multirow{2}{*}{$\begin{array}{l}\text { Deforestation since year of } \\
\text { implementation } \\
\mathrm{km}^{2}\end{array}$} & \multicolumn{2}{|c|}{$\begin{array}{l}\text { Number of FMD } \\
\text { vaccines } \\
\text { administered and } \\
\text { administration } \\
\text { points (2014) }\end{array}$} & \multicolumn{2}{|c|}{$\begin{array}{l}\text { Environmental } \\
\text { embargos } \\
(2002-2014)\end{array}$} & \multicolumn{3}{|c|}{$\begin{array}{l}\text { Farm holdings and cattle } \\
\text { population (2014) } \\
\text { affected by embargos }\end{array}$} \\
\hline & & & Count & Head & Count & $\mathrm{km}^{2}$ & Count & $\mathrm{km}^{2}$ & Head \\
\hline Agrarian settlement projects & 2707.2 & 601.8 & 472 & 103,630 & 293 & 247.1 & 18 & 93.2 & 10,933 \\
\hline PDS Nelson de Oliveira (2006) & 46.6 & 5.9 & 1 & 510 & 1 & 0.1 & 0 & 0 & 0 \\
\hline PA Nova Fronteira (1996) & 161.5 & 63.7 & 118 & 12,448 & 43 & 8.1 & 1 & 0.8 & 304 \\
\hline PA Santa Julia (1997) & 283.9 & 134.1 & 134 & 18,865 & 35 & 28.7 & 2 & 1.6 & 173 \\
\hline PDS Terra Nossa (2006) & 1491.6 & 239.5 & 98 & 44,572 & 94 & 129.3 & 5 & 63.2 & 5323 \\
\hline PA Esperança (2006) & 149.6 & 30.7 & 51 & 11,712 & 27 & 12.3 & 1 & 6.6 & 1736 \\
\hline PDS Esperança (2006) & 180.5 & 22.9 & 5 & 3280 & 18 & 24.2 & 0 & 0 & 0 \\
\hline PDS Brasília (2005) & 199.7 & 75.0 & 52 & 7028 & 46 & 17.8 & 5 & 5.2 & 1094 \\
\hline PDS Mãe Menininha (2006) & 193.7 & 30.0 & 13 & 5215 & 29 & 26.7 & 4 & 15.8 & 2303 \\
\hline Federal protected areas & $39,677.8$ & 1070.2 & 275 & 176,842 & 425 & 704.3 & 26 & 366.4 & 23,489 \\
\hline APA Tapajós (2006) & $12,080.0$ & 128.6 & 35 & 8972 & 33 & 37.8 & 0 & 0 & 0 \\
\hline FLONA Altamira (1998) & 4021.3 & 273.3 & 19 & 8437 & 51 & 183.4 & 4 & 12.7 & 2695 \\
\hline FLONA Crepori (2006) & 1072.8 & 1.9 & 1 & 165 & 0 & 0.0 & 0 & 0 & 0 \\
\hline FLONA Jamanxim (2006) & $13,011.1$ & 551.8 & 169 & 122,159 & 310 & 459.0 & 21 & 349.5 & 20,335 \\
\hline PARNA Jamanxim (2006) & 1512.4 & 18.9 & 2 & 369 & 8 & 13.1 & 0 & 0 & 0 \\
\hline PARNA Rio Novo (2006) & 4555.4 & 9.2 & 5 & 3092 & 0 & 0.0 & 0 & 0 & 0 \\
\hline $\begin{array}{l}\text { REBIO Nascentes da Serra do } \\
\text { Cachimbo (2005) } \\
\text { State-protected areas }\end{array}$ & 3424.8 & 86.6 & 44 & 33,648 & 23 & 10.9 & 1 & 4.2 & 459 \\
\hline FE Iriri (2006) & 3055.7 & 20.5 & 2 & 2155 & 6 & 2.8 & 0 & 0 & 0 \\
\hline Indigenous territories & $14,626.6$ & 35.9 & 1 & 578 & 25 & 3.3 & 0 & 0 & 0 \\
\hline TI Baú (2004) & 9510.5 & 2.9 & 0 & 0 & 18 & 0.6 & 0 & 0 & 0 \\
\hline TI Mekragnotí (1994) & 1815.8 & 1.0 & 1 & 578 & 2 & 1.9 & 0 & 0 & 0 \\
\hline TI Panará (2002) & 539.0 & 1.0 & 0 & 0 & 0 & 0.0 & 0 & 0 & 0 \\
\hline TI Cayabi (2003) & 1709.5 & 31.0 & 0 & 0 & 5 & 0.8 & 0 & 0 & 0 \\
\hline TI Kuruáya (2005) & 111.9 & 0.0 & 0 & 0 & 0 & 0.0 & 0 & 0 & 0 \\
\hline TI Munduruku (2004) & 939.8 & 0.0 & 0 & 0 & 0 & 0.0 & 0 & 0 & 0 \\
\hline \multicolumn{10}{|l|}{ Military area } \\
\hline Cachimbo (1984) & $22,238.2$ & 169.4 & 7 & 7342 & 18 & 41.5 & 0 & 0 & 0 \\
\hline Other area & $24,794.9$ & 7499.7 & 2078 & 887,496 & 1220 & 2112.5 & 105 & 840.2 & 75,832 \\
\hline Sum & $107,100.4$ & 9397.5 & 2835 & $1,178,043$ & 1987 & 3111.5 & 149 & 1299.8 & 110,254 \\
\hline
\end{tabular}

Sources: ADEPARÁ (2014), IBAMA (2014), IBGE (2015), INPE (2015)

governmental and non-governmental organizations associated with the livestock, agriculture, and environmental lobbies or associations across local, state, and federal scales (e.g., Novo Progresso, Santarém, Sinop, Belém, Brasília). Field interviews also included a series of interdisciplinary, in-depth farm surveys with ranchers and farmers around Novo Progresso (e.g., Boy et al. 2016). Some of these interviews were conducted, as a component of a biographic narrative project on the linkages among migration, land use decisions, environmental perceptions, and sociocultural background along the BR-163 highway (Schumann et al. 2015).

\section{Results}

The 2009 TAC agreements sought to remove cattle from any areas which (a) were located in restricted areas, (b) were deforested since the TAC agreement was put into place in July 2009, (c) were under an environmental property embargo by IBAMA, (d) were not included in the eligible CAR area, or (e) were linked to slave labor. To test how effective the TAC agreements were in Southwest Pará, we overlaid the ADEPARÁ vaccination data over (a) protected area boundaries, (b) PRODES annual deforestation data, (c) 
environmental embargo data, (d) CAR data, and (f) checked cross-references with the publicly available list of slave labor. We then determined the proportion of the cattle herd grazing in areas which should have been off limits, given the TAC agreements.

In Novo Progresso, ADEPARÁ recorded 612,000 vaccinations administered in more than 1500 locations. One hundred seventy-five of these sites were in restricted areas; an additional 26 were on ranches which had deforested after 2009, and an additional 73 properties were under some form of an embargo.

Across Southwest Pará, ADEPARÁ recorded more than 1.1 million FMD vaccines on 2800 locations. Nearly 500 of these locations, per the TAC agreement, should have been excluded from the cattle supply chain. In total, 285 of the vaccination locations were in restricted areas (protected areas, indigenous lands, and military area). An additional 63 administration points were ranches which deforested after 2009. Another 149 administration points were under some form of environmental embargo (Table 4; Fig. 3). Considering the Brazilian law situation, our analysis highlights a series of failures with respect to the enforcement of several key environmental laws in the Amazon. This includes the 2012 Forest Code (Federal Law 12.651/2012), the 2000 National System of Conservation Units (SNUC, Federal Law 9.985/2000), the Law of Public Forests (Federal Law 11.285/2006), the Environmental Crimes Law (Federal Law 9.605/98, Decree 3.179/99), and the Law of Land Regularization (Federal Law 11.952/2009) (Brito and Cardoso 2015; Pacheco and Benatti 2015).

Many of the cattle in restricted areas were in the Jamanxim National Forest, a vast tract of protected land lying to the west of the BR-163 highway. When the Jamanxim National Forest was created in 2006, many of the ranchers who had already informally occupied areas within the zones (including approximately 28,000 ha of disputed property) refused to leave their lands (Campbell 2015; Coy and Klingler 2013; Melo et al. 2009). Despite numerous law enforcement and control operations, arrests, and herd seizures, the majority of these ranches continued to operate. We estimated that in 2014, approximately 120,000 cattle were vaccinated in ranchlands (with an average property size of 2.300 ha) inside the Jamanxim National Forest, an area which, to TAC signatories, should have been excluded from the supply chain.

Large numbers of cattle were grazing on areas which were deforested between 2010 and 2014. Compared to the number of cattle grazing in restricted areas, the portion of the cattle herd on newly deforested pastures was relatively small (15 vs. $3 \%$ ); however, 20,000 head were vaccinated on areas deforested after 2009. Forty percent of these cattle were located on relatively smaller properties (less than 300 ha). This suggests that small-scale to medium-scale landowners, who represent more than half of the local cattle businesses, may have been less responsive to control mechanisms. This finding
Table 4 Illegal cattle existence in Southwest Pará (2014)

\begin{tabular}{|c|c|c|c|c|}
\hline & \multicolumn{2}{|c|}{ Southwest Pará } & \multicolumn{2}{|c|}{ Novo Progresso } \\
\hline & Count & Head & Count & Head \\
\hline \multicolumn{5}{|c|}{ 1. Cattle in restricted areas (2014) } \\
\hline $\mathrm{UCF}$ & 275 & 176,842 & 171 & 123,083 \\
\hline UCE & 2 & 2155 & 0 & 0 \\
\hline TI & 1 & 578 & 0 & 0 \\
\hline $\mathrm{AM}$ & 7 & 7342 & 4 & 6112 \\
\hline Sum & 285 & 186,917 & 175 & 129,195 \\
\hline \multicolumn{5}{|c|}{$\begin{array}{l}\text { 2. Cattle on annual deforestation plots (criteria of illegality referring to } \\
\text { TAC August 2009) }\end{array}$} \\
\hline 2010 & 10 & 3772 & 3 & 136 \\
\hline 2011 & 15 & 10,094 & 5 & 256 \\
\hline 2012 & 12 & 2994 & 7 & 2778 \\
\hline 2013 & 19 & 2605 & 9 & 1382 \\
\hline 2014 & 7 & 1200 & 2 & 146 \\
\hline Sum & 63 & 20,665 & 26 & 4698 \\
\hline \multicolumn{5}{|c|}{ 3. Cattle on embargoed areas (IBAMA 2000-2014) } \\
\hline $2000-2003$ & 0 & 0 & 0 & 0 \\
\hline 2004-2008 & 38 & 31,869 & 13 & 11,147 \\
\hline 2009-2011 & 77 & 57,846 & 47 & 33,656 \\
\hline $2012-2014$ & 34 & 20,512 & 13 & 7246 \\
\hline Sum & 149 & 110,254 & 73 & 52,049 \\
\hline \multicolumn{5}{|c|}{ 4. Cattle on CAR properties in Novo Progresso (2009-2014) } \\
\hline \multicolumn{5}{|l|}{ Temporary CAR } \\
\hline Forest reserve $<50 \%$ & & & 51 & 14,431 \\
\hline Forest reserve $50-79 \%$ & & & 320 & 159,873 \\
\hline Forest reserve $>80 \%$ & & & 305 & 134,768 \\
\hline \multicolumn{5}{|l|}{ Definitive CAR } \\
\hline Forest reserve $<50 \%$ & & & 5 & 719 \\
\hline Forest reserve $50-79 \%$ & & & 26 & 5445 \\
\hline Forest reserve $>80 \%$ & & & 8 & 2030 \\
\hline Sum with CAR & & & 715 & 317,266 \\
\hline Sum without CAR & & & 699 & 166,243 \\
\hline
\end{tabular}

Sources: ADEPARÁ (2014), IBAMA (2014), IBGE (2015), INPE (2014), SEMAS-PA (2014)

is to some extent supported by evidence that enforcement operations have focused on larger ranches (MMA and IBAMA 2014). Small ranchers may also have avoided regulations meant to be imposed through the TAC or G4 agreements by focusing on calf production (the more laborintensive portion of the cattle process) and serving primarily as indirect suppliers to larger ranches. More than one half of cattle grazing on smaller properties with recent deforestation activities were less than 1 year old.

In addition to showing clear evidence of cattle in restricted areas and on recently deforested properties, the ADEPARÁ vaccination data also suggested that cattle were grazing on areas which were embargoed, in direct violation of Federal 


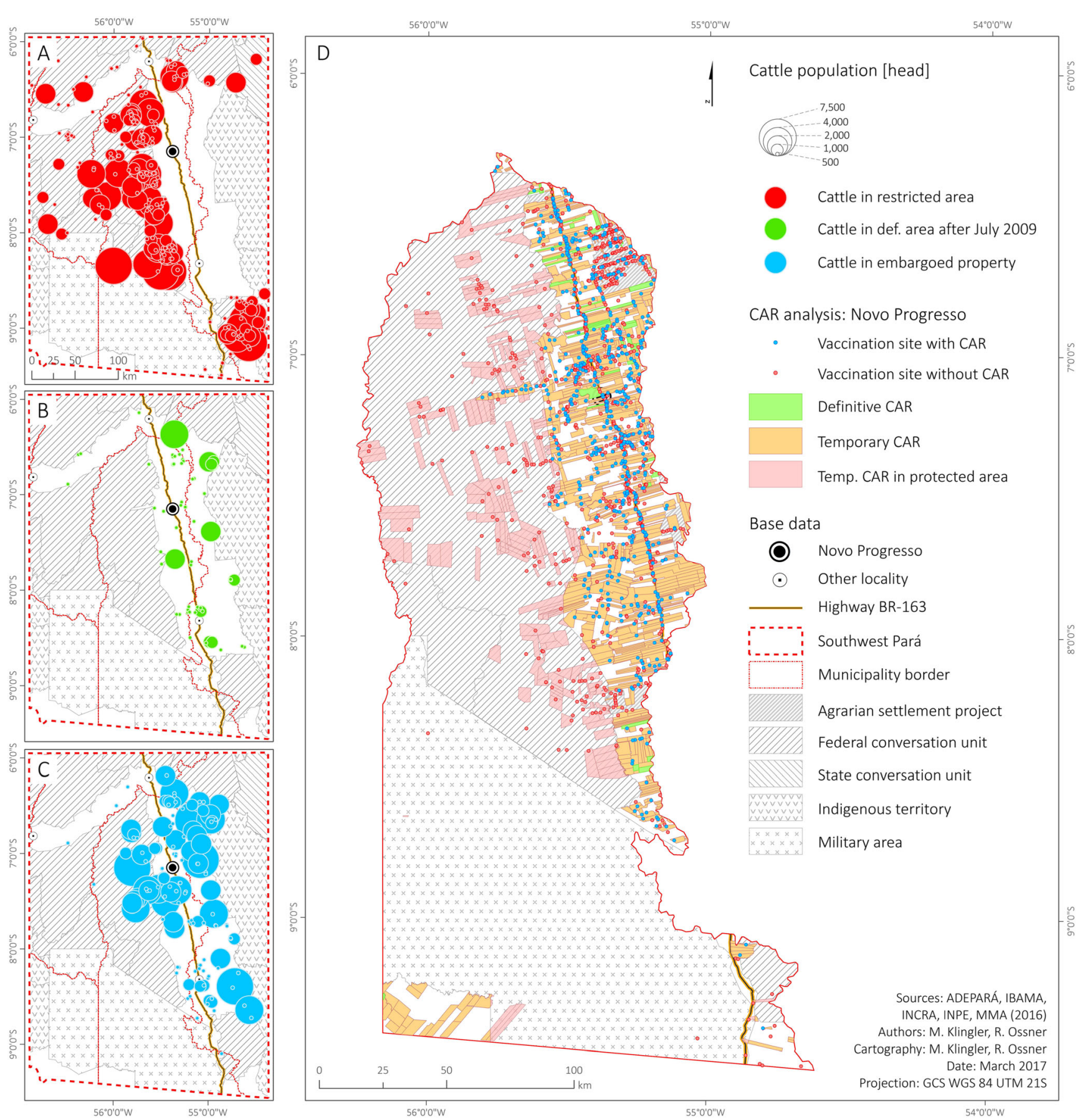

Fig. 3 Number and location of foot-and-mouth disease vaccinations administered in (a) restricted areas, (b) areas which had deforested after 2009, (c) embargoed properties, and, for Novo Progresso only, (d) areas with and without CAR registrations

Decree 6.321/07, which was meant to exclude some of the worst violators of environmental laws from the cattle supply chain. More than 100,000 head of cattle, or $10 \%$ of the total herd in southwestern Pará, were vaccinated on embargoed ranches. These cattle were largely concentrated in three key areas (Fig. 2): (a) the Jamanxim National Forest, (b) agrarian settlement projects, and (c) the remote regions located east of Novo Progresso, which pertained to the municipality of Altamira.
Finally, approximately 160,000 head of cattle were grazing on areas which were not registered in the CAR system. Of these, only $3 \%$ were on areas which possessed a definitive CAR (only 50 properties had received a definitive CAR). The analysis of the temporary CAR showed us severe problems of overlaps, multiple registries, and substantial gaps in the demarcation of the legal requirements (Permanent Preservation Area (APP); Legal Forest Reserve (RL)). Only a small fraction of $5 \%$ met the new Forest Code requirement to 
maintain an $80 \%$ legal forest reserve. In addition, we identified 330 of invalid CAR registries claiming regularization outside the eligible reference area, mainly in the Jamanxim National Forest. Still, these temporary documents will be applied to legalize cattle outside the eligible CAR area.

\section{Discussion and conclusion}

The cattle sector has grown tremendously in the Amazon over the past 2 decades, due to the control of FMD (Bowman 2016), rapid improvements in accessibility, increased slaughterhouse capacity (Walker et al. 2009), and a decade of strong economic growth and poverty alleviation (leading to greater domestic demand for beef). In the process, a market-oriented culture of cowboys is now pervasive across central and northern Brazil, from Pará to Mato Grosso, and beyond, to the western Amazon (Hoelle 2015). Across much of the Amazon today, cattle (and the cowboy) are king. The cattle sector, however, has been closely tied to forest loss.

An innovative array of government policies and the creation of several supply chain interventions, including the publically supported and legally binding cattle agreements which were central to this analysis, were critical steps towards decoupling cattle from deforestation. However, this research showed significant shortcomings to the existing cattle agreements. Notably, it showed that hundreds of thousands of cattle continue to graze on areas which should have been excluded from the cattle supply chain in the Amazon.

While our data could not provide conclusive evidence of cattle laundering, or other mechanisms from which to evade the guidelines set forth under the cattle agreements, interviews conducted by the lead author with ranchers and key political and industry figures in and around the region between 2010 and 2014 did offer insight into both how and why ranches which should have been excluded by the cattle agreements continue to operate. With respect to how, ranchers demonstrated a number of avenues for avoiding the potential repercussions of the supply chain. Besides the option that ranchers could sell to non-TAC signatories, many of these avenues stem from an inability, or lack of will, to track cattle before their final sale to a given slaughterhouse. This means that cattle are prone to laundering, or where animals raised on areas which for one or another reason are effectively out of compliance could be sold to intermediaries or supplying ranches who did meet legal requirements and could then sell the animals directly to a signatory slaughterhouse. Notably, interviews suggested that cattle could be associated with a clean property at the point of sale. In other cases, ranchers had multiple properties or CAR registrations. If some of these registrations were embargoed, incomplete, or in a restricted area, the rancher could associate his or her animals with a parcel which was registered and in compliance, even if the cattle were produced on a property(ies) which was not. The tolerance of inaccurate CAR registries and weak tracing mechanisms of cattle origin, as well as the strong involvement of indirect suppliers in the cattle supply chain, erases, in the end, any traces of illegal cattle by excluding them from current cattle agreements.

The cattle observed in out-of-compliance areas in Southwest Pará were not meant exclusively for the local market. In 2014, when the data for this analysis was collected, no slaughterhouses were operating in the region with permits to export across state or federal borders. ${ }^{1}$ Three slaughterhouses with a total capacity to slaughter 20 animals per day officially operated under state inspection without permission to export interstate. A range of small abattoirs worked without official inspection in Novo Progresso, Castelo dos Sonhos, and Moraes de Almeida, largely for local markets. The lack of local processing capacity implies that the local herd was likely processed outside of the region. These findings are largely aligned with recent work by Barreto et al. (2017), which suggested that Southwest Pará is a key supply region for slaughterhouses in Mato Grosso (where $60 \%$ of the federal and stateinspected slaughterhouses signed the TAC agreements). Interviews with ranchers indicated that calves were largely being sold to major Brazilian signatory meatpacking companies JBS and Redentor, both of which operated slaughterhouses in Northern Mato Grosso. Recently, questions have also emerged with respect to slaughterhouses' own efforts to comply with the cattle agreements. In 2017, as part of IBAMA operation Cold Meat (Carne Fria), 11 slaughterhouses, including 2 slaughterhouses owned by JBS, were penalized in southeastern Pará state for accepting fraudulent documents and purchasing meat from properties embargoed due to illegal deforestation (Locatelli and Aranha 2017).

Interviews across the BR-163 region also offer some insight into why cattle persist in the Novo Progresso region and why it will likely persist into the future. Notably, the persistence of vast forest land, low land prices, weak land tenure regularization, and rapidly improving roads, infrastructure, and beef markets were regularly cited as driving the region's growth. Ambiguities around land tenure laws have also been especially critical in not only driving deforestation but also providing an incentive for landowners to stock newly opened areas with cattle. Deforestation remains a crucial strategy for achieving land tenure security in what remains a scramble for land in Novo Progresso. Conversely, abandoning pasture might be construed as abandoning what might already be tenuous private claims on property, often to public land. Yet, for those living in or operating pastures in areas with tenuous land rights, to cease their operations, even after

\footnotetext{
${ }^{1}$ One federally inspected slaughterhouse, with a capacity to slaughter 500 cattle per day, opened in Novo Progresso in late 2015, after this analysis. The slaughterhouse, however, has since been closed.
} 
property confiscations, fines, or official embargos, would be to relinquish what could be their strongest claim to their land: active use and possession. Cattle production, in some sense, thus becomes about more than pure rent-seeking production, and maintaining an active herd can be critical for maintaining tenuous land security and thus has a "social function" (Miccolis et al. 2014). This may be especially clear west of Novo Progresso, in the Jamanxim National Forest, where continued cattle operations have helped to secure rural producer's land occupation interests within the park. Nevertheless, according to ICMBio, $67 \%$ of these large-scale properties were installed after the creation in 2006 and $60 \%$ of the owners do not reside there but in Mato Grosso or São Paulo (Melo et al. 2009). What social and environmental right groups criticize a promising strategy for regularizing invaded public lands (Martins et al. 2017) ultimately favored the argument to reduce the area of Jamanxim National Forest by more than 50\%, to lower the protection status in the remaining areas, and to facilitate infrastructure measures (see Provisory Measures, MPs 756/2016; 758/2016).

Issues or limitations to land tenure security also limit landowners' abilities to intensify access to agricultural credit, and commodity markets, owing to the soybean moratorium, also limit options for farmers who wish to recuperate degraded pastureland with soybean cultivation (e.g., through the Federal Low-Carbon Agriculture Programs). In this sense, once landowners are cast out of programs which facilitate legal access to land or agricultural credit, they may be locked into a system of illegal cattle production. Consequently, regularizing land tenure in the region and developing pathways for legalizing existing herds will be critical for developing and maintaining a regulated supply chain. Considering the $75 \%$ increase of the deforestation rate since 2012 (INPE 2017), the recent government's course of legalizing illegal operations within protected areas or violations of the Forest Code in private lands definitely sends out ambivalent signals when it comes to resolve the environmental dimension of land tenure insecurity (Benatti and da Cunha Fischer 2017).

In the coming years, we hope that more research will critically evaluate the impact of the TAC and G4 zerodeforestation agreements across the Amazon. We also hope that this article can foster more discussions on how cattle can be better tracked, particularly in more remote areas of the Amazon such as Novo Progresso.

Reigning in the cattle sector in the Amazon, particularly in its more remote reaches, will require more intensive and more precise tracking systems, and perhaps new financial tools capable of further reweighting incentives for land clearing (Barreto and Gibbs 2015; Cohn et al. 2014; Nepstad et al. 2009). However, short of GPS tracking, such tools may well exist. As part of the FMD control system, cattle are tracked across their lifetimes through vaccination cards, which certify the health of their animals. Such a system, in theory, could be appropriate for also certifying the location of cattle and for tying cattle locations to the potential multiple ranches on which they have lived. However, to ensure accurate traceability of cattle, enhancing transparency in the supply chain, e.g., public access to cattle transportation data, is key.

Acknowledgements Open access funding provided by University of Innsbruck and Medical University of Innsbruck. We want to thank all involved farmers, institutions, and the Brazilian counterpart project Carbioma (UFMT, UFPA-NAEA, Embrapa Arroz e Feijão) for collaboration and the anonymous reviewers for their support to improve the manuscript. Peter Richards currently serves as an Economic Adviser for the Bureau for Food Security with the US Agency for International Development. The views and opinions expressed in this paper are those of the authors and not necessarily the views and opinions of the US Agency for International Development.

Funding information This research is part of the Brazilian-German cooperation project Carbon sequestration, biodiversity and social structures in Southern Amazonia (Carbiocial) funded by the German Federal Ministry of Education and Research (BMBF; project no. 01LL09021).

Open Access This article is distributed under the terms of the Creative Commons Attribution 4.0 International License (http:// creativecommons.org/licenses/by/4.0/), which permits unrestricted use, distribution, and reproduction in any medium, provided you give appropriate credit to the original author(s) and the source, provide a link to the Creative Commons license, and indicate if changes were made.

\section{References}

ADEPARÁ (2013) Portaria Nr. 0409/2013. Belém

ADEPARÁ (2014) Programa de erradicação da febre aftosa regional Novo Progresso. Belém

ADEPARÁ (2017) Adepará emitiu quase 550 mil guias de trânsito animal em 2016. http://www.adepara.pa.gov.br/index.php?adepara=nav/ single\&topico $=578$. Accessed 15 Apr 2017

Araújo E, Barreto P, Martins H (2015) Áreas protegidas críticas na Amazônia no período de 2012 a 2014. Belém

Arima EY, Barreto P, Araújo E, Soares-Filho B (2014) Public policies can reduce tropical deforestation: lessons and challenges from Brazil. Land Use Policy 41:465-473. https://doi.org/10.1016/j.landusepol. 2014.06.026

Assunção J, Rocha R (2014) Getting greener by going black: the priority municipalities in Brazil. Technical Paper. Climate Policy Initiative, PUC-Rio, Rio de Janeiro

Azevedo, DQF (2014) O tratamento dado aos empresários agrários nos TACs assinados por frigoríficos situado estado do Pará. In: Âmbito Jurídico. http://www.ambito-juridico.com.br/site/?n_link=revista artigos leitura\&artigo $\mathrm{id}=14211$ \&revista caderno $=5$. Accessed 30 Sep 2016

Azevedo AA, Rajão R, Costa M, Stabile MCC, Alencar A, Moutinho P (2014) Cadastro Ambiental Rural e sua influência na dinâmica do desmatamento na Amazônia Legal. Boletim Amazônia em Pauta, IPAM, Brasília

Azevedo AA, Stabile MCC, Reis TNP (2015) Commodity production in Brazil: combining zero deforestation and zero illegality. Elem Sci Anthr 3:76. 10.12952/journal.elementa.000076

Barreto P, Gibbs HK (2015) Como melhorar a eficácia dos acordos contra o desmatamento associado à pecuária na Amazônia? University of Wisconsin-Madison, Belém, Imazon 
Barreto P, Silva D (2011) Will cattle ranching continue to drive deforestation in the Brazilian Amazon? Belém

Barreto P, Pereira R, Brandão A Jr, Baima S (2017) Os frigoríficos vão ajudar a zerar o desmatamento da Amazônia? Imazon. Instituto Centro da Vida, Belém

Benatti JH, da Cunha Fischer LR (2017) New trends in land tenure and environmental regularisation laws in the Brazilian Amazon. Reg Environ Chang. https://doi.org/10.1007/s10113-017-1162-0

Börner J, Kis-Katos K, Hargrave J, König K (2015) Post-crackdown effectiveness of field-based Forest law enforcement in the Brazilian Amazon. PLoS One 10:e0121544. https://doi.org/10. 1371/journal.pone.0121544

Bowman MS (2016) Impact of foot-and-mouth disease status on deforestation in Brazilian Amazon and cerrado municipalities between 2000 and 2010. J Environ Econ Manage 75:25-40. https://doi.org/ 10.1016/j.jeem.2015.08.003

Boy J, Strey S, Schönenberg R, Strey R, Weber-Santos O, Nendel C, Klingler M, Schumann C, Hartberger K, Guggenberger G (2016) Seeing the forest not for the carbon: why concentrating on land-useinduced carbon stock changes of soils in Brazil can be climate-unfriendly. Reg Environ Chang. https://doi.org/10.1007/s10113-0161008-1

Brito B, Cardoso Jr D (2015) Regularização Fundiária no Pará: afinal, qual o problema? Belém

Campbell JM (2014) Speculative accumulation: property-making in the Brazilian Amazon. J Lat Am Caribb Anthropol 19:237-259. https:// doi.org/10.1111/jlca.12078

Campbell JM (2015) The land question in Amazonia: cadastral knowledge and ignorance in Brazil's tenure regularization program. PoLAR. Polit Leg Anthropol Rev 38:147-167. https://doi.org/10. 1111/plar.12091

Castro, EMR, de Santos, RAO, de Rocha, GM, de Sá, MER, da Silva, RNM, de Pereira, CLO (2010) Socioeconomia. In: Venturieri A, Monteiro M de A, Menezes CRC (eds) Zoneamento EcológicoEconômico da Zona Oeste do Estado do Pará, Volume 1. Embrapa Amazônia Oriental, Belém, pp 33-116

CEPAL, IPEA, GIZ (2011) Avaliação do Plano de Ação para Prevenção e Controle do Desmatamento na Amazônia Legal. PPCDAm 20072010. CEPAL, IPEA, GIZ, Brasília

Chomitz KM, Wertz-Kanounnikoff S (2005) Measuring the initial impacts on deforestation of Mato Grosso's program for environmental control. The World Bank

Cisneros E, Zhou SL, Börner J (2015) Naming and shaming for conservation: evidence from the Brazilian Amazon. PLoS One 10: e0136402. https://doi.org/10.1371/journal.pone.0136402

Cohn AS, Mosnier A, Havlik P, Valin H, Herrero M, Schmid E, O'Hare M, Obersteiner M (2014) Cattle ranching intensification in Brazil can reduce global greenhouse gas emissions by sparing land from deforestation. Proc Natl Acad Sci 11:7236-7241. https://doi.org/10. 1073/pnas.1307163111

Coy M, Klingler M (2013) Novo Progresso: Ein emblematischer Ort der Widersprüchlichkeiten Amazoniens. In: De Araújo SH de, Schmitt T, Tschorn L (eds) Widerständigkeiten im Land der Zukunft. Andere Blicke auf und aus Brasilien. Unrast Verlag, Münster, pp 310-319

Coy M, Klingler M, Kohlhepp G (2017) De frontier até pós-frontier. Confins. https://doi.org/10.4000/confins.11683

DeFries RS, Herold M, Verchot L, Macedo MN, Shimabukuro Y (2013) Export-oriented deforestation in Mato Grosso: harbinger or exception for other tropical forests? Philos Trans R Soc B Biol Sci 368: 20120173-20120173

Fearnside PM (2007) Brazil's Cuiabá-Santarém (BR-163) Highway: the environmental cost of paving a soybean corridor through the Amazon. Environ Manag 39:601-614. https://doi.org/10.1007/ s00267-006-0149-2

Garcia-Drigo I, Piketty M-G, Poccard-Chapuis R, Pacheco P, Thalês M, Abramovay R (2016) Governing the beef supply chain in the
Brazilian Amazon: progress and limits in shaping the transition towards a sustainable development. In: International Conference on Agri-Chains and Sustainable Development. CIRAD, Montpellier, pp 16-19

Gibbs HK, Munger J, L'Roe J, Barreto P, Pereira R, Christie M, Amaral T, Walker NF (2015a) Did ranchers and slaughterhouses respond to zero-deforestation agreements in the Brazilian Amazon? Conserv Lett 9:32-42. https://doi.org/10.1111/conl.12175

Gibbs HK, Rausch L, Munger J, Schelly I, Morton DC, Noojipady P, Soares-Filho B, Barreto P, Micol L, Walker NF (2015b) Brazil's Soy Moratorium. Science (80- ) 347:377-378. doi: https://doi.org/10. 1126/science.aaa0181

Greenpeace Brasil (2009) A farra do boi na Amazônia. Greenpeace Brasil, São Paulo

Greenpeace International (2009) Minimum criteria for industrial scale cattle operations in the Brazilian Amazon Biome

Helfand SM, Castro de Rezende G (2004) The impact of sector-specific and economy-wide policy reforms on the agricultural sector in Brazil: 1980-98. Contemp Econ Policy 22:194-212. https://doi. org/10.1093/cep/byh014

Hoelle J (2015) Rainforest cowboys: the rise of ranching and cattle culture in Western Amazonia. University of Texas Press, Austin

INPE (2017) Taxas anuais do desmatamento - 1988 até 2016. Proj. PRODES, In. http://www.obt.inpe.br/prodes/index.php

INPE, Embrapa (2016) Dados TerraClass 2004, 2008, 2010, 2012, 2014. Proj. Terraclass. Leventamento informações uso e Cober. da terra na Amaz, In http://www.inpe.br/cra/projetos_pesquisas/terraclass2012. php. Accessed 1 Aug 2016

Kaimowitz D, Mertens B, Wunder S, Pacheco P (2004) Hamburger connection fuels Amazon destruction: cattle ranching and deforestation in Brazil's Amazon. Bogor

Locatelli P, Aranha A (2017) JBS compra gado de áreas desmatadas ilegalmente e leva multa de R \$24 milhões. Repórter Bras, In http://reporterbrasil.org.br/2017/03/jbs-compra-gado-de-areasdesmatadas-ilegalmente-e-leva-multa-de-r24-milhoes/. Accessed 24 Mar 2017

Macedo MN, DeFries RS, Morton DC, Stickler CM, Galford GL, Shimabukuro YE (2012) Decoupling of deforestation and soy production in the southern Amazon during the late 2000s. Proc Natl Acad Sci 109:1341-1346. https://doi.org/10.1073/pnas.1111374109

MAPA (2005) Orientações para fiscalização do comércio de vacinas contra a febre aftosa e para controle e avaliação das etapas de vacinação. Brasília

MAPA (2007) Instrução Normativa Nr. 44, 0210/2007. Brasília

MAPA (2016a) Resultados da vacinação contra Febre Aftosa do $1^{\circ}$ semestre de 2016 - Brasil. Brasília

MAPA (2016b) Resultados da vacinação contra Febre Aftosa do $2^{\circ}$ semestre de 2016 - Brasil. Brasília

Martins H, Vedoveto M, Araújo E, Barreto P, Baima S, Souza C Jr, Veríssimo A (2012) Critical protected areas in the Brazilian Amazon. IMAZON, Belém

Martins H, Ribeiro J, Souza Jr. C (2017) Evolução da pressão Jamanxim (2006 a 2017). Belém

Melo RF, Souza PFM de, Pentead DB, Paiva Jr. LH de, Cohenca D (2009) Estudo Técnico de Revisão dos limites da Floresta Nacional do Jamanxim. Brasília

Meyer C, Miller D (2015) Zero deforestation zones: the case for linking deforestation-free supply chain initiatives and jurisdictional REDD+ . J Sustain For 34:559-580. https://doi.org/10.1080/10549811.2015. 1036886

Miccolis A, de Andrade, RMT, Pacheco P (2014) Land-use trends and environmental governance policies in Brazil: paths forward for sustainability. Bogor

MMA, IBAMA (2014) Relatório de Áreas Embargadas. In: Consult. Pública Autuações Ambient. e Embargos. https://servicos.ibama. 
gov.br/ctf/publi co/arease mbargad a s / ConsultaPublicaAreasEmbargadas.php. Accessed 10 Dec 2014

Moutinho P, Guerra R, Azevedo-Ramos C (2016) Achieving zero deforestation in the Brazilian Amazon: what is missing? Elem Sci Anthr 4:125. https://doi.org/10.12952/journal.elementa.000125

MPF (2009a) Termo de compromisso do governo do Estado do Pará. Belém

MPF (2009b) Termo de ajuste de conduta (TAC) - Bertin. Belém

MPF (2010) Termo de ajuste de conduta assinado (TAC) - JBS. Cuiabá

MPF (2014) Operação desmonta maior quadrilha de desmatadores da região. In: Notícias da Procur. da República no Pará. http://www. prpa.mpf.mp.br/news/2014/operacao-desmonta-maior-quadrilhade-desmatadores-da-regiao-amazonica. Accessed 10 Feb 2016

Nepstad DC, Stickler CM, Almeida OT (2006) Globalization of the Amazon soy and beef industries: opportunities for conservation. Conserv Biol 20:1595-1603. https://doi.org/10.1111/j.1523-1739. 2006.00510.x

Nepstad D, Soares-Filho BS, Merry F, Lima A, Moutinho P, Carter J, Bowman M, Cattaneo A, Rodrigues H, Schwartzman S, McGrath DG, Stickler CM, Lubowski R, Piris-Cabezas P, Rivero S, Alencar A, Almeida O, Stella O (2009) The end of deforestation in the Brazilian Amazon. Science 326:1350-1351. https://doi.org/10. 1126/science. 1182108

Nepstad DC, McGrath DG, Stickler CM, Alencar A, Azevedo AA, Swette B, Bezerra T, DiGiano M, Shimada J, Seroa da Motta R, Armijo E, Castello L, Brando PM, Hansen MC, McGrath-Horn M, Carvalho O, Hess L (2014) Slowing Amazon deforestation through public policy and interventions in beef and soy supply chains. Science (80- ) 344:1118-1123. https://doi.org/10.1126/ science. 1248525

Pacheco P, Benatti JH (2015) Tenure security and land appropriation under changing environmental governance in lowland Bolivia and Pará. Forests 6:464-491. https://doi.org/10.3390/f6020464

Pacheco P, Piketty M-G, Poccard-Chapuis R, Garcia-Drigo I, El Husny JC, Gomes M, Tourrand J-F (2017) Beyond zero deforestation in the Brazilian Amazon: progress and remaining challenges to sustainable cattle intensification

Pires MO (2013) O Cadastro Ambiental Rural. Das origens às perspectivas para a política ambiental. Conservação Internacional Brasil, Brasília

Rausch L, Gibbs HK (2016) Property arrangements and soy governance in the Brazilian state of Mato Grosso: implications for deforestationfree production. Land 5:7. https://doi.org/10.3390/land5020007

Richards PD, VanWey L (2015) Farm-scale distribution of deforestation and remaining forest cover in Mato Grosso. Nat Clim Chang 6:418 425. https://doi.org/10.1038/nclimate2854
Richards PD, Myers RJ, Swinton SM, Walker RT (2012) Exchange rates, soybean supply response, and deforestation in South America. Glob Environ Chang 22:454-462. https://doi.org/10.1016/j.gloenvcha. 2012.01.004

Richards PD, Walker RT, Arima EY (2014) Spatially complex land change: the indirect effect of Brazil's agricultural sector on land use in Amazonia. Glob Environ Chang 29:1-9. https://doi.org/10. 1016/j.gloenvcha.2014.06.011

Rudorff BFT, Adami M, Aguiar DA, Moreira MA, Mello MP, Fabiani L, Amaral DF, Pires BM (2011) The soy moratorium in the Amazon biome monitored by remote sensing images. Remote Sens 3:185202. https://doi.org/10.3390/rs3010185

Schmitt J (2015) Crime sem castigo: a efetividade da fiscalização ambiental para o controle do desmatamento ilegal na Amazônia. Universidade de Brasília

Schumann C, Hartberger K, Klingler M, Schönenberg R (2015) Sempre pra frente. Histórias de vida da BR 163. Editora Olhares, São Paulo

Sills EO, Herrera D, Kirkpatrick AJ, Brandão A, Dickson R, Hall S, Pattanayak S, Shoch D, Vedoveto M, Young L, Pfaff A (2015) Estimating the impacts of local policy innovation: the synthetic control method applied to tropical deforestation. PLoS One 10:1-15. https://doi.org/10.1371/journal.pone.0132590

Soares-Filho B, Rajão R, Macedo M, Carneiro A, Costa W, Coe M, Rodrigues H, Alencar A (2014) Cracking Brazil's Forest Code. Science 344:363-364. https://doi.org/10.1126/science.1246663

Sousa PQ (2016) Decreasing deforestation in the southern Brazilian Amazon - the role of administrative sanctions in Mato Grosso state. Forests 7:1-22. https://doi.org/10.3390/f7030066

Stickler CM, Nepstad DC, Azevedo AA, McGrath DG (2013) Defending public interests in private lands: compliance, costs and potential environmental consequences of the Brazilian Forest code in Mato Grosso. Philos Trans R Soc B Biol Sci 368:20120160-20120160. https://doi.org/10.1098/rstb.2012.0160

Torres M, de Oliveira AU, Oliveira BC, Fearnside PM, Aragão J, Orrico R, Rocha J, Figueiredo W, Filho AC, Arbex J Jr (2005) Amazônia revelada: os descaminhos ao longo da BR -163. CNPQ, Brasília

Walker R, Browder J, Arima E, Simmons C, Pereira R, Caldas M, Shirota R, de ZS (2009) Ranching and the new global range: Amazônia in the 21st century. Geoforum 40:732-745. https://doi.org/10.1016/j. geoforum.2008.10.009

Walker NF, Patel SA, Kalif KAB (2013) From Amazon pasture to the high street: deforestation and the Brazilian cattle product supply chain. Trop Conserv Sci Spec Issue 6:446-467

WDPA (2016) World Database on Protected Areas. www. protectedplanet.net. Accessed 14 Oct 2016 